\title{
Reproductive inhibition in the Cape porcupine, Hystrix africaeaustralis
}

\author{
R. J. van Aarde and V. van Wyk \\ Mammal Research Institute, Department of Zoology, University of Pretoria, Pretoria 0002, \\ South Africa
}

\begin{abstract}
Summary. Sexually mature female Cape porcupines kept under natural conditions of illumination and temperature did not conceive while housed within their natal groups. Before removal from their natal groups the sexually mature offspring copulated and experienced cyclic ovarian activity, but conception occurred only 70-120 days after dispersal. Mean oestrous cycle length of these females $(36.9 \pm 11.5$ days; $n=34)$ was similar to that of breeding females $(33.0 \pm 11.64$ days; $n=16)$, but mean peak plasma progesterone concentration $(6.45 \pm 6.03 \mathrm{ng} / \mathrm{ml} ; n=34)$ was significantly $(P<0.01)$ lower than that of cyclic breeding females $(13.58 \pm 6.98 \mathrm{ng} / \mathrm{ml} ; n=16)$. Mean progesterone concentration at oestrus in non-breeding females $(0.72 \pm 0.45 \mathrm{ng} / \mathrm{ml}$; $n=34)$ was also significantly $(P<0.01)$ lower than that of non-pregnant breeding females $(4 \cdot 21 \pm 2.44 \mathrm{ng} / \mathrm{ml} ; n=16)$. Reproductive inhibition within natal groups, in which only one female reproduces, therefore cannot be ascribed to a failure to copulate, but may be due to some factor inhibiting full expression of luteal activity or affecting ovulation.
\end{abstract}

Keywords: porcupines; reproductive inhibition; oestrus; progesterone

\section{Introduction}

The Cape porcupine, Hystrix africaeaustralis, is a large $(12-18 \mathrm{~kg})$ hystricomorph rodent which occurs throughout most of the southern African subregion. Cape porcupines, like the related Indian porcupine, $H$. indica, are apparently monogamous (Morris \& van Aarde, 1985; Sever \& Mendelssohn, 1988) and live in extended family groups, each of these consisting of a breeding male, breeding female and offspring of consecutive years (van Aarde, 1987a) with a single litter being produced annually during the warm months in the summer-rainfall areas of South Africa (van Aarde, 1985a). They are nocturnal and burrow dwelling and forage solitarily or in groups of 2 or 3, these comprising an adult male and offspring and in some cases accompanied by an adult female with or without their offspring (van Aarde, 1987a). Cape porcupines are polyoestrous with each oestrous cycle lasting 17-42 days (mean 31.2, s.d. = 6.5 days; van Aarde, 1985b). Lactational anoestrus lasts $101 \pm 37.8$ days and females experience 3-7 post-lactational cycles before conceiving (van Aarde, 1985a). Components of sexual behaviour (approaching, solicitation and mounting) occur during all days of the oestrous cycle (Morris \& van Aarde, 1985) and during all stages of pregnancy and lactation (unpublished observations). When given the opportunity in captivity the male will mate with other females in the colony without any interference from the breeding female.

Although mated, females (except one breeding female) do not conceive while in the groups in which they were born. Dispersal apparently is a prerequisite for conception (van Aarde, 1987a) and this has important implications for the regulation of population size (van Aarde, 1987b).

The social environment to which female mammals are exposed can affect onset of puberty and individual reproductive output (see Weir, 1971; McClintock, 1983; Marchlewska-Koj, 1984; 
Vandenbergh, 1983; Abbott, 1988a; Lusk \& Millar, 1989, for references). Socially induced reproductive suppression or inhibition occurs in a wide variety of species (reviewed by Wasser \& Barash, 1983; Abbott, 1988b) and has been implicated in stabilizing numbers in natural populations (Vandenbergh, 1983).

The present paper describes the endocrine status following the manifestation of reproductive inhibition in the female Cape porcupine by quantifying plasma progesterone concentrations, and hence ovarian activity, in females housed singly with breeding males and in females housed in their natal groups with breeding males.

\title{
Materials and Methods
}

\begin{abstract}
Animals. Eight sexually mature ( $>24$ months of age; see van Aarde, 1985a) Cape porcupine females, born in captivity under conditions as described by van Aarde (1985c), were housed in 4 separate enclosures, each enclosure holding an adult male known to be fertile. Two breeding females ( 3 and 4 years old) were housed without offspring and 2 ( 5 and 6 years old) were housed each with 2 female offspring. All females were therefore at least 2 years of age but the 4 offspring ( 2 and 3 years old) had stayed within their natal colonies and had not produced offspring before the onset of the study. At 15 months after the onset of the study each of the 4 offspring were removed from their natal groups and housed in 4 separate enclosures with males known to be fertile.
\end{abstract}

Blood sampling. Blood $(\sim 5.0 \mathrm{ml})$ was collected from the femoral vein into heparinized tubes at 5-7-day intervals for 570-760 days from each of these females after they had been immobilized by an intramuscular injection of a mixture of ketamine hydrochloride (Ketalar: Parke-Davis Laboratories (Pty) Ltd, Isando, South Africa) and xylazine hydrochloride (Rompun: Bayer Pharmaceuticals (Pty) Ltd, Johannesburg, South Africa) (van Aarde, 1985b). Blood samples were kept on ice and were centrifuged within $30 \mathrm{~min}$ after collection. Plasma was removed and stored at $-20^{\circ} \mathrm{C}$ until assayed. At the time of immobilization the lactational status and condition of the vaginal closure membrane were noted. The length of the oestrous cycle was taken as the interval from the first day of vaginal opening in one cycle to the day before opening in the following cycle (see van Aarde, 1985b). Enclosures were inspected daily for the presence of copulatory plugs and, later, newly produced offspring. Day of conception was calculated as day of birth minus 94 days (see van Aarde, 1985a).

Radioimmunoassay of progesterone. Plasma progesterone concentrations were determined as described by van Aarde (1985b) and van Aarde \& Potgieter (1986). Extraction efficiency and the volume of plasma extracted were taken into account when calculating final concentrations using the programme SECURIA 2200 (Packard Instrument Co., Downers Grove, IL, USA).

The antiserum used (No. 1529) differed from that used by van Aarde (1985b) and van Aarde \& Potgieter (1986); it was supplied by R. P. Millar (Department of Chemical Pathology, University of Cape Town, South Africa), and was raised in a rabbit against progesterone-21-bovine serum albumin. Cross-reactions with other steroids were: pregnenolone, $3.1 \%$; 17 $\alpha$-hydroxyprogesterone, $1.9 \% ; 11 \alpha$-hydroxyprogesterone, $25.8 \% ; 11 \beta$-hydroxyprogesterone, $47 \cdot 1 \% ; 5 \alpha$-pregnane-3, 20-dione, $24 \cdot 8 \% ; 20 \alpha$-hydroxy-4-pregnane-3-one, $0.4 \% ; 11$-deoxycorticosterone, $2 \cdot 2 \% ; 3 \alpha$ hydroxy-5-pregnane-20-one, $0.4 \%$; 11-deoxycortisol, $1.5 \%$; cortisol, $<0.2 \%$; testosterone, 4-androstenedione, $17 \beta$ oestradiol and oestrone, $<0.001 \%$. The sensitivity of the assays, defined as two standard deviations of the zero standard was $0.16 \mathrm{ng} / \mathrm{ml}$. The recovery of known amounts of progesterone (4-pregnene-3,20-dione; Sigma Chemical Co., Poole, Dorset, UK) added to a plasma pool did not differ significantly from expected values. Serially diluted plasma samples exhibited displacement curves parallel to the standard curve. The mean \pm s.d. recovery of unlabelled progesterone added to a plasma pool was $87 \cdot 3 \pm 2 \cdot 8 \%(n=4)$. Recovery of $\left[1,2,6,7 \cdot{ }^{3} \mathrm{H}\right]$ progesterone (Radiochemical Centre, Amersham, Bucks, UK) varied from 80.1 to $87.6 \%$ (mean $83.9 \pm 3.4 ; n=4$ ) in samples from non-pregnant females and from 68.2 to $72 \cdot 1 \%$ (mean $69.9 \pm 1 \cdot 6 ; n=4$ ) in samples from pregnant females. The relative low recovery estimates for samples from pregnant females is ascribed to the presence of plasma progesterone binding proteins (see van Aarde \& Potgieter, 1986). Intra- and inter-assay coefficients of variation were 1.4 and $2.7 \%$ respectively.

All mean values in the text are followed by one standard deviation of the mean and statistical significance for differences is based on Student's $t$ test. Frequencies are compared using $\chi^{2}$-values determined as part of contingency table analyses.

\section{Results}

Direct observations and the presence of copulatory plugs in vaginas confirmed that all females copulated. The 2 females housed singly with an adult male and the 2 females housed with their offspring conceived and gave birth at least twice during the 750-day study period. Progesterone 


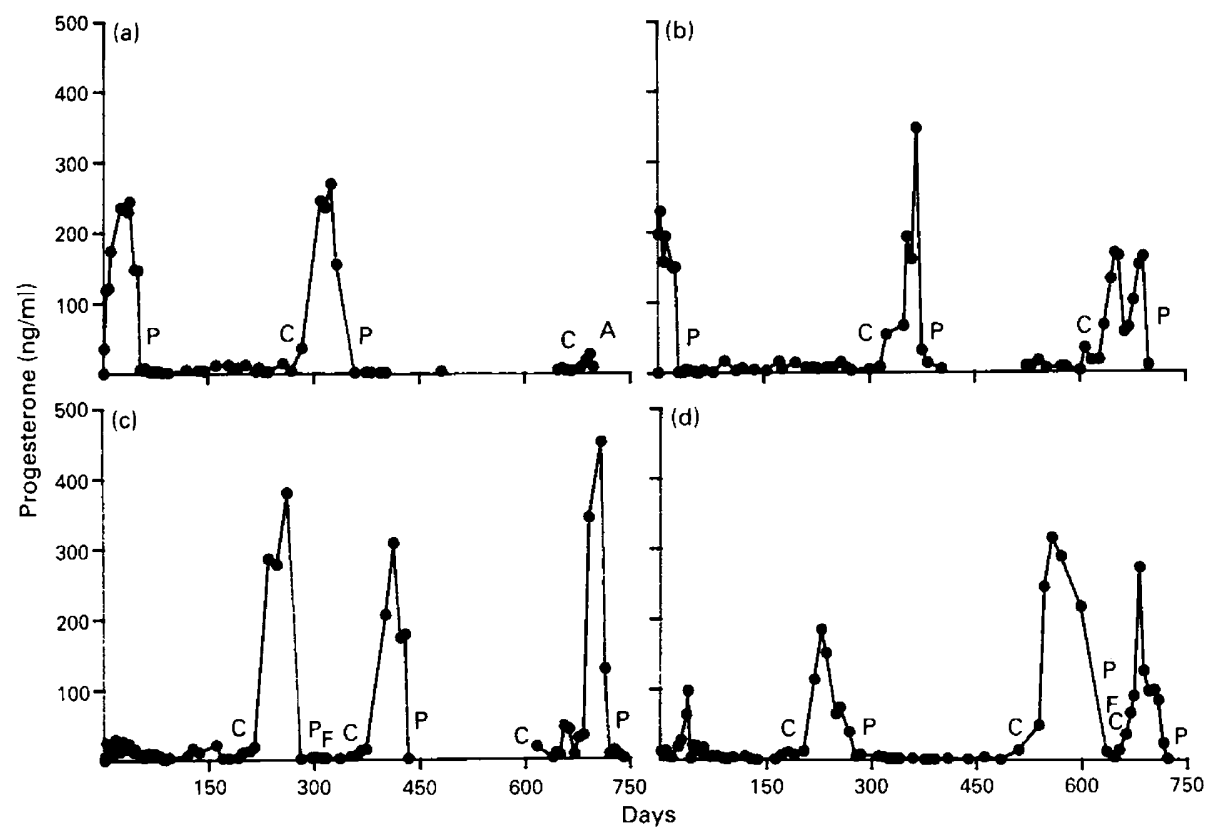

Fig. 1. Temporal changes in plasma progesterone concentrations in 4 breeding female Cape porcupines. $\mathrm{A}=$ aborted; $\mathrm{C}=$ conception; $\mathrm{F}=$ forced weaning; $\mathrm{P}=$ parturition.

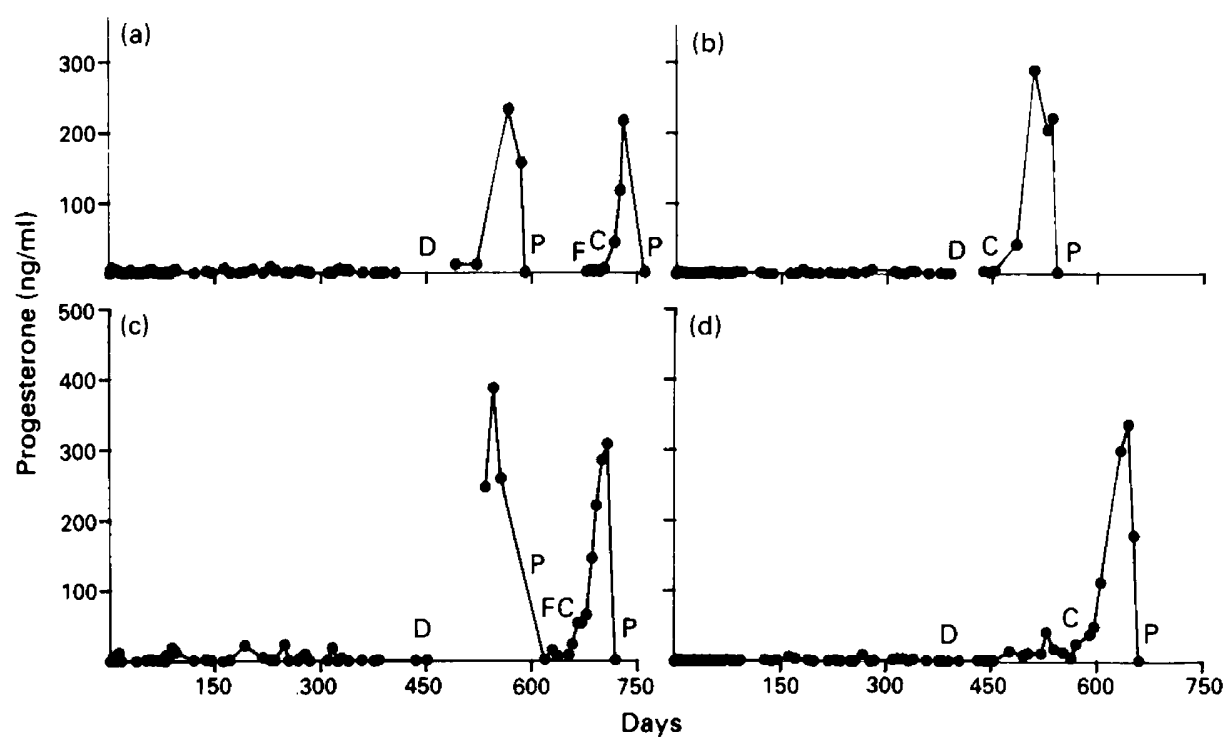

Fig. 2. Temporal changes in plasma progesterone concentrations in 4 female Cape porcupines before and after dispersal. $\mathrm{C}=$ conception; $\mathrm{D}=$ dispersal from natal colonies; $\mathrm{F}=$ forced weaning; $\mathrm{P}=$ parturition.

profiles compiled for these females (Fig. 1) illustrate that they reproduced at least once annually, with conception intervals being affected by the survival of offspring (Fig. 1c \& d). Preceding removal from their natal groups, the sexually mature offspring housed in their natal groups did not 


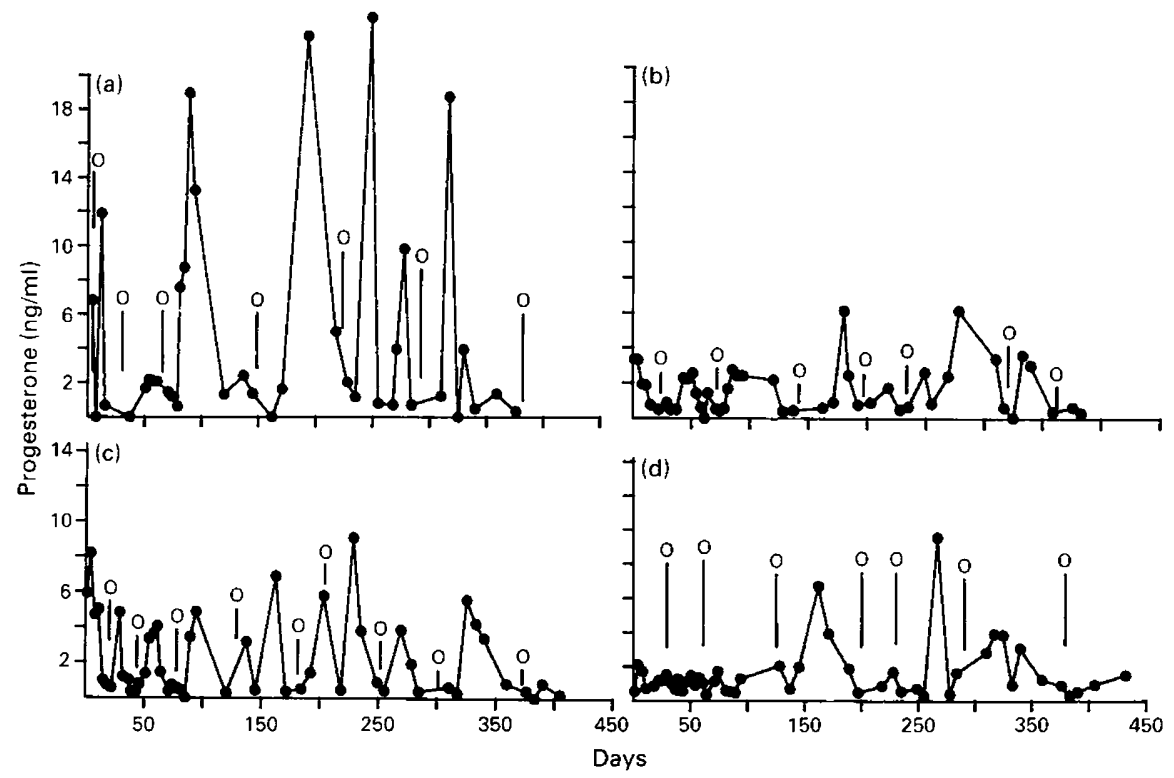

Fig. 3. Temporal changes in plasma progesterone concentrations in 4 adult non-breeding Cape porcupine females before dispersal from their natal colonies. $\mathrm{O}=$ oestrus.

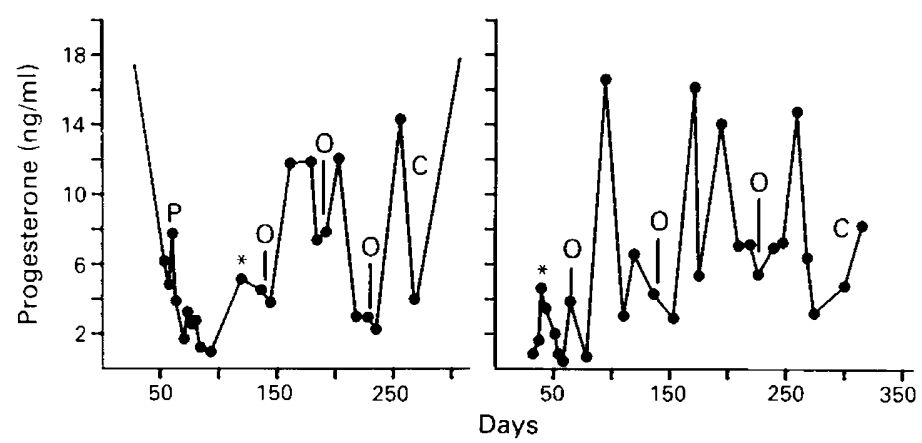

Fig. 4. Temporal changes in plasma progesterone concentrations in breeding female Cape porcupines during the parturition-conception interval. $\mathrm{P}=$ parturition; ${ }^{*}=$ end of lactation; $\mathrm{C}=$ conception.

reproduce and plasma progesterone concentrations in these females remained $<20 \mathrm{ng} / \mathrm{ml}$ (Fig. 2). All 4 of these females, however, did experience cyclic ovarian activity before dispersion (Fig. 3 ) and conceived 70-120 days after dispersal (Fig. 2).

Lactational anoestrus in females suckling their young to weaning age (mean 104.6 $\pm 19 \cdot 3$ days; $\mathrm{N}=9$ ) was followed by the occurrence of 3 or 4 oestrous cycles (Fig. 4) each of these lasting 18-51 days (mean $33 \pm 11 \cdot 6$ days; $n=16$ ). Females kept in their natal colonies also experienced consecutive periods of oestrus (Fig. 3) with the mean length of oestrous cycles $(36.9 \pm 11.5$ days; range 16-62 days, $n=34)$ not differing significantly $(P<0.01)$ from that experienced by breeding females between the end of lactation and conception. Mean peak plasma progesterone concentration in cyclic breeding females (mean $13.58 \pm 6.98 \mathrm{ng} / \mathrm{ml} ; n=16)$ was significantly $(P<0.01)$ higher than the mean peak value in cyclic non-breeding females (mean $6.45 \pm 6.03 \mathrm{ng} / \mathrm{ml} ; n=34$ ). Mean progesterone concentration at oestrus in breeding females (mean $4.21 \pm 2.44 \mathrm{ng} / \mathrm{ml} ; n=16$ ) 
was also significantly higher than that of non-breeding females (mean $0.72 \pm 0.45 \mathrm{ng} / \mathrm{ml} ; n=34$ ) at oestrus. Peak progesterone values in most (13 out of 16) of the oestrous cycles of breeding females exceeded $5.0 \mathrm{ng} / \mathrm{ml}$ while only 14 of the 34 cycles of non-breeding females were characterized by peak levels $>5 \mathrm{ng} / \mathrm{ml}$.

In breeding females progesterone concentration at the oestrus followed by conception (mean $6.09 \pm 1.51 \mathrm{ng} / \mathrm{ml} ; n=10$ ) did not differ significantly from that at an oestrus not followed by conception.

\section{Discussion}

Socially induced infertility occurs in many species of free-living mammals (see Harcourt, 1987; Kawata, 1987; Abbott, 1988a; Lusk \& Millar, 1989) and usually results from dominant individuals suppressing reproduction in subordinate individuals. Reproduction is either suppressed by an inhibition of ovulation (e.g. naked mole-rats, Heterocephalus glaber: Abbott et al., 1989; marmoset monkeys, Callithrix jacchus: Abbott et al., 1988) or interruption of sexual behaviour by the dominant female (e.g. wolves, Canis lupus: Mech, 1970; dwarf mongooses, Helogale parvula: Rood, 1980). In some species subordinate females may conceive but intervention by the dominant female usually results in the young of the subordinate dying soon after birth (e.g. dwarf mongooses: Rasa, 1979; Cape wild dogs, Lycaon pictus: Malcolm \& Marten, 1982). Reproductive suppression in the Cape porcupine, however, cannot be ascribed to any of these mechanisms and requires further investigation.

The present investigation confirms that porcupine females do not breed in their natal colonies and that dispersal is a prerequisite for conception (see van Aarde, 1987b). Since all non-breeding females were either seen copulating and/or had copulatory plugs present in their vaginal channels, their failure to reproduce cannot be ascribed to them not copulating. Morris \& van Aarde (1985) reported on captive breeding males copulating with more than one female within the family group when solicited, but clearly illustrated that copulation with non-breeding females is initiated by the female. Copulation with the breeding female is initiated by either partner. From this, Morris \& van Aarde (1985) proposed monogamy as a possible mating system in Cape porcupines, a suggestion supported by the observations of Sever \& Mendelssohn (1988) and van Aarde (1987a, b) who found adult pairs either foraging or sharing a burrow to be of the opposite sex, in spite of the reproductive status of the female.

The length of the oestrous cycles reported here for breeding and non-breeding females is similar to that recorded earlier for primiparous and parous porcupine females (van Aarde, 1985a). Absolute progesterone values during the oestrous cycle and during pregnancy are higher, however, than those recorded by van Aarde (1985b) and van Aarde \& Potgieter (1986), probably because of the differences in the cross-reactivities of the antisera used for the assays in the 3 studies.

Similar lengths of the oestrous cycles of breeding and non-breeding females and cyclic changes in plasma progesterone concentrations suggest that the failure of females to reproduce in the natal colonies is not due to a failure of cyclic ovarian activity or to pseudopregnancy (see van Aarde, 1984). The significant differences in plasma progesterone concentrations of breeding and nonbreeding females during the oestrous cycle do, however, suggest that cyclic progesterone secretion in non-breeding females is affected (but not inhibited) by external factors to which the females are exposed while present in their natal colonies. The mechanism(s) involved and the factors affecting luteal activity, or the full expression of luteal activity in these females, are as yet not known. Nonbreeding females experienced consecutive periods of oestrus, which in the porcupine is associated with the perforation of the vaginal membrane and peaks in oestradiol-17 $\beta$ secretion (van Aarde, 1985b). Cyclic changes in plasma progesterone concentrations in these females may therefore be ascribed to cyclic changes in ovarian activity. These progesterone profiles, however, could have been caused by the cyclic induction of luteinized follicles, without ovulation occurring. This is 
supported by the presence of corpora lutea, accessory corpora lutea and corpora atretica in the ovaries of all non-pregnant, non-lactating adult females $(\mathrm{N}=33)$ collected as part of a cropping programme (see van Aarde \& Skinner, 1986). Factors other than the inhibition of luteal activity may, however, also contribute to the inhibition of reproduction.

The most obvious difference in plasma progesterone concentrations of cyclic breeding and non-breeding females is that values in breeding females during all phases of the cycle are higher than those in non-breeding females (Figs $3 \& 4$ ). Progesterone concentrations during oestrus followed by conception were significantly higher than those recorded during oestrus in mated nonbreeding females. The failure of females to reproduce in their natal colonies may therefore be caused by insufficient progesterone for the preparation of the uterus for implantation, or for the maintenance of early (preimplantation) pregnancy. Since progesterone values during oestrus followed by conception did not differ from those during oestrus not followed by conception in breeding females, the above would, however, not explain why breeding females experience a number of oestrous cycles before conceiving. In the latter group, failure to conceive can also not be ascribed to failure of early luteal activity since peak progesterone concentrations during the luteal phase of the cycle were similar to those recorded during early pregnancy.

The University of Pretoria and the Foundation for Research Development provided logistical and financial support.

\section{References}

Abbott, D.H. (1988a) Natural suppression of fertility. Symp. zool. Soc. Lond. 60, 7-28.

Abbott, D.H. (1988b) Social suppression of reproduction in primates. In Comparative Socioecology: the Behavioural Ecology of Humans and Other Mammals, pp. 285-304. Eds V. Standen \& R. A. Foley. Blackwell Scientific Publications, Oxford.

Abbott, D.H., Hodges, J.K. \& George, L.M. (1988) Social status control LH secretion and ovulation in female marmoset monkeys (Callithrix jacchus). J. Endocr. 117, 329-339.

Abbott, D.H., Barrett, J., Faulkes, C.G. \& George, L.M. (1989) Social contraception in naked mole-rats and marmoset monkeys, J. Zool., Lond. 219, 703-710.

Harcourt, A.H. (1987) Dominance and fertility among female primates. J. Zool., Lond. 213, 471-487.

Kawata, M. (1987) Pregnancy failure and suppression by female-female interaction in enclosed populations of the red-backed vole, Clethrionomys rufocanus bedfordiae. Behav. Ecol. Sociobiol. 20, 89-97.

Lusk, S.J.G. \& Millar, J.S. (1989) Reproductive inhibition in a short-season population of Peromyscus maniculatus. J. Anim. Ecol. 58, 329-341.

Malcolm, J.R. \& Marten, K. (1982) Natural selection and the communal rearing of pups in African wild dogs (Lycaon pictus). Behav. Ecol. Sociobiol. 10, 1-13.

Marchlewska-Koj, A. (1984) Pheromones and mammalian reproduction. Oxford Rev. Reprod. Biol. 6, 266-302.

McClintock, M.K. (1983) Pheromonal regulation of the ovarian cycle: enhancement, suppression and synchrony. In Pheromones and Reproduction in Mammals, pp. 113-149. Ed. J. G. Vandenbergh. Academic Press, New York.

Mech, D. (1970) The Wolf: The Ecology and Behaviour of an Endangered Species. The Natural History Press, New York.
Morris, D. \& van Aarde, R.J. (1985) Sexual behaviour of the female porcupine, Hystrix africaeaustralis. Horm. Behav. 19, 400-412.

Rasa, O.A.E. (1979) The effects of crowding on the social relationships and behaviour of the dwarf mongoose (Helogale undulata rufula). Z. Tierpsychol. 49, 317-329.

Rood, J.P. (1980) Mating relations and breeding suppression in the dwarf mongoose. Anim. Behat. 28, 14. 150.

Sever, Z. \& Mendelssohn, H. (1988) Copulation as a possible mechanism to maintain monogamy in porcupines, Hystrix indica. Anim. Behar. 36, 1541-1558.

van Aarde, R.J. (1984) Reproduction in the porcupine Hystrix africaeaustralis Peters. D.Sc. thesis, University of Pretoria, Pretoria.

van Aarde, R.J. (1985a) Reproduction in captive female Cape porcupines (Hystrix africaeaustralis). $J$. Reprod. Fert. 75, 577-582.

van Aarde, R.J. (1985b) Circulating progesterone and oestradiol-17$\beta$ concentrations in cyclic Cape porcupines, Hystrix africaeaustralis. J. Reprod. Fert. 75, 583-591.

van Aarde, R.J. (1985c) Husbandry and immobilization of captive porcupines Hystrix africaeaustralis. S. Afr. J. Wildl. Res. 15, 77-79.

van Aarde, R.J. (1987a) Demography of a Cape porcupine, Hy:strix africaeaustralis, population. J. Zool., Lond. 213, 205-212.

van Aarde, R.J. (1987b) Reproduction in the porcupine (Hystrix africaeaustralis): an ecological perspective. S. Afr. J. Sci. 83, 605-607.

van Aarde, R.J. \& Potgieter, H.C. (1986) Circulating progesterone, progesterone-binding proteins and oestradiol- $17 \beta$ concentrations in the pregnant Cape 
porcupine, Hystrix africaeaustralis. J. Reprod. Fert. 76, $561-567$.

van Aarde, R.J. \& Skinner, J.D. (1986) Functional anatomy of the ovaries of pregnant and lactating Cape porcupines, Hystrix africaeaustralis. J. Reprod. Fert. 76, 553-559.

Vandenbergh, J.G. (1983) Pheromonal regulation of puberty. In Pheromones and Reproduction in Mammals, pp. 95-1 12. Ed. J. G. Vandenbergh. Academic Press, New York.
Wasser, S.K. \& Barash, D.P. (1983) Reproductive suppression among female mammals: implications for biomedicine and sexual selection theory. $Q$. Rev. Biol. 58, 513-538.

Weir, J. (1971) The evocation of oestrus in the cuis, Galea musteloides. J. Reprod. Fert. 26, 405-408.

Received 3 March 1990 